\title{
You can't always get what you want: How entrepreneur's perceived resource needs affect the incubator's assertiveness
}

\author{
Marijn van Weele ${ }^{\mathrm{a}, *}$, Frank J. van Rijnsoever ${ }^{\mathrm{a}}$, Frans Nauta ${ }^{\mathrm{b}}$ \\ ${ }^{a}$ Innovation Studies, Copernicus Institute of Sustainable Development, Utrecht University, Heidelberglaan 2, 3584 CS Utrecht, The Netherlands \\ ${ }^{\mathrm{b}}$ Haas School of Business, UC Berkeley, 2220 Piedmont Avenue, Berkeley, CA 94720, USA
}

\section{A R T I C L E I N F O}

\section{Article history:}

Received 10 July 2014

Received in revised form

24 August 2016

Accepted 25 August 2016

Available online 13 September 2016

Keywords:

Entrepreneurs

Business support

Incubators

Resource needs

Start-ups

\begin{abstract}
A B S T R A C T
A possible explanation for the disappointing performance of incubators is that start-ups do not take full advantage of the resources offered by the incubator. In explaining the low usage of the incubator's resources, existing studies neglect that incubated entrepreneurs may not be aware of the gaps in their resource base. Using qualitative data from six European incubators, we identify start-ups' resource needs as perceived by incubator staff and by entrepreneurs. Further, we explore the implications of differences in perceptions for the incubator's assertiveness. We find that entrepreneurs are unable to use the incubator's resources to develop missing intangible resources: entrepreneurs are not aware of their resource gaps, hesitant to step out of their comfort zone, and primarily short-term oriented. In order to ensure that start-ups develop a comprehensive resource base, incubators supporting early stage startups were found to take an assertive strategy, creating self-awareness among entrepreneurs, and encouraging them to make use of the incubator's resources. Our study adds to current incubator literature by providing a more comprehensive explanation for the low usage of the incubator's resources, by identifying circumstances under which an assertive strategy is desirable and by exploring the practices through which an assertive strategy can be implemented.
\end{abstract}

(c) 2016 Elsevier Ltd. All rights reserved.

\section{Introduction}

Incubators have become an institutionalized component of world-wide policies that aim to stimulate entrepreneurship, innovation and economic growth (Ahmad and Ingle, 2013; Mian et al., 2016; Oakey, 2012). There are currently about 7000 incubators around the world, most of which are supported by local or national governments (Aerts et al., 2007; Dee et al., 2011; InBIA, 2016). These incubators provide start-ups with a broad range of services and resources, such as a physical infrastructure, business services, specialized technological knowledge, and a comprehensive support network (Aerts et al., 2007; Bruneel et al., 2012; Theodorakopoulos et al., 2014). As such, incubators have the potential to complement the resource base of start-ups and to facilitate their survival and growth. The popularity of incubators suggests that they are effective instruments to support start-ups. However, while some studies have shown that start-ups in incubators have higher chances of survival or growth (Ferguson and Olofsson, 2004; Mian, 1997; Stokan et al., 2015), there is a vast

\footnotetext{
* Corresponding author.

E-mail addresses: m.a.vanweele@uu.nl (M. van Weele), f.j.vanrijnsoever@uu.nl (F.J. van Rijnsoever), nauta@berkeley.edu (F. Nauta).
}

amount of empirical work showing that incubators do not help in promoting the success of start-ups (Oakey, 2012; Ratinho and Henriques, 2010; Schwartz, 2013, 2009; Tamásy, 2007; Tavoletti, 2013).

Recent studies show that start-ups do not take full advantage of the incubator's resources, which could partly explain these disappointing results. For example, while incubators organize training and coaching programs for entrepreneurs to acquire necessary business knowledge, participation in these sessions tends to be low (Patton and Marlow, 2011; Patton, 2014). Similarly, incubators enable start-ups to network with peers and external actors, but many entrepreneurs do not engage in these networking activities (Bruneel et al., 2012; Schwartz and Hornych, 2010). These findings suggest that entrepreneurs and incubator staff have different perceptions about the importance of the incubator's resources: while incubator staff feels that their training, coaching and networking are of great importance to incubated start-ups, entrepreneurs apparently do not agree (Patton, 2014).

The extant literature provides two explanations for these differences in perceptions that primarily point at the incubator. First, entrepreneurs may not make use of the incubator's resources when these are of insufficient quality. For example, entrepreneurs may be unwilling to take advice from mentors who lack experience (Lalkaka, 2001; Rice, 2002), and they may not engage in 
networking activities when the incubator's networks are underdeveloped (Patton, 2014; Totterman and Sten, 2005). A second explanation is that incubators do not sufficiently take the needs of the incubated start-ups into account, which results in a mismatch between the resources provided by incubators and the resources needed by start-ups. Ratinho and Henriques (2010) argue that the incubator's services are too rigid, as they are not tailored to the specific needs of individual start-ups. Bruneel et al. (2012) finds that the incubator's resources are superfluous, as incubators support mature start-ups that already have a solid resource base. These mature start-ups have no need for the incubator's support which is more tailored to the needs of early stage start-ups.

A third explanation, which has received less attention, points at the incubated entrepreneurs. These entrepreneurs often have a technological background and little entrepreneurial experience (Rice, 2002; Scillitoe and Chakrabarti, 2010). Such entrepreneurs may not recognize the gaps in their resource base (Oakey, 2003; Vohora et al., 2004). Hence, they may be unable to recognize the value of the incubator's resources (Patton, 2014). Still, it has not yet been explored which specific resources entrepreneurs undervalue.

Therefore, our first research question is: "which resources, provided by the incubator, do entrepreneurs and incubator staff perceive as important, and why do their perceptions differ?"

The explanation for these differences in perceptions has important implications for incubators. If the incubator's resources are of insufficient quality or not in line with the needs of start-ups, then incubators need to focus on developing their resources and listen more carefully to the needs of entrepreneurs. On the other hand, if entrepreneurs are insufficiently aware of the needs of their start-up, then merely providing resources on the request of entrepreneurs is not sufficient for incubators. Incubators should then actively identify the needs of start-ups and stimulate entrepreneurs to make use of the incubator's resources that fit these needs (Patton, 2014; Rice, 2002). Accordingly, the explanation for differences in perceptions affects the incubator's 'assertiveness', which refers to the extent to which incubators "see themselves as managers of the incubation process or as external facilitators of a process primarily managed by the incubatees themselves" (Bergek and Norrman, 2008 p. 24). Therefore, our second research question is: "what do these differences in perceptions imply for the incubator's assertiveness?"

To answer these questions, we conducted a total of 66 interviews with incubator staff and incubated entrepreneurs in Europe. Entrepreneurs initially did not perceive business knowledge to be important, and were not willing to develop this resource because they were hesitant to step out of their comfort zone and primarily short term oriented. Incubators supporting early stage start-ups with first-time entrepreneurs were therefore highly assertive, using various practices to stimulate entrepreneurs to develop particular resources. Our study provides additional explanations for the low usage of the incubator's resources, and identifies possible responses. It also serves as a practical guideline for incubators and policy makers to help start-ups overcome their resource needs.

In the remainder of this paper, we first discuss literature on entrepreneurship and incubators, followed by the research methods. We then present our findings. This paper ends with a discussion and conclusion.

\section{Theory}

This section develops a framework that guides our data collection and analysis. We first draw on the resource-based view (RBV) to identify and categorize both the resources that start-ups need to survive as well as the resources that incubators may provide. This categorization will be used in the empirical part to outline the perceptions of entrepreneurs and incubator managers regarding the importance of the incubator's resources. We then explore how incubators can intervene in the incubation process by discussing the concept of incubator assertiveness.

\subsection{Start-up needs and incubator support: resources}

According to the RBV, firms can be seen as a bundle of tangible and intangible resources (Barney, 1991; Wernerfelt, 1984), with resources being "stocks of available factors that are owned or controlled by the firm" (Amit and Schoemaker, 1993, p. 35). The competitive advantage of firms lies in their valuable, rare, inimitable, and non-substitutable resources (Amit and Schoemaker, 1993; Oliver, 1997). In contrast with established organizations, the resource base of start-ups is incomplete and still developing, which contributes to the 'liabilities of newness' of such firms (Stinchcombe, 1965). From a resource-based perspective, incubators are seen as addressing these liabilities of newness by providing a resource-rich environment that enables start-ups to complement their resource base (Albert and Gaynor, 2001; McAdam and McAdam, 2008). As such, incubators can provide resources directly, or enable start-ups to access resources externally through the incubator's networks (Amezcua et al., 2013; Gassmann and Becker, 2006). The following list of resources is not exhaustive, but it outlines the most important resources that startups need to survive and grow. In discussing each resource type, we first provide a definition. We then discuss the resource in the context of start-ups, after which we discuss how incubators can support start-ups by providing this resource. Table 1 provides an overview.

\subsubsection{Tangible resources}

- Physical capital includes the physical technology used in a firm, the firm's plant and equipment, its location, and its access to raw materials (Barney, 1991). Physical capital may be difficult to find and expensive to acquire on the small scale needed by start-ups. Incubators can provide physical capital and economies of scale by providing shared office space and facilities such as equipment, meeting rooms or a reception (Bergek and Norrman, 2008). University affiliated incubators can also provide access to specialized physical capital, such as university libraries and laboratories (Mian, 1997).

- Financial capital entails all of the different monetary resources available for the discovery and exploitation of the venture idea (Barney, 1991). Start-ups often need high amounts of financial capital for costly research and development at the pre-sales stage (Westhead and Storey, 1997). At the same time, financiers see start-ups as high risk investments due to the novelty and complexity of their technology (Carpenter and Petersen, 2002; Gompers and Lerner, 2001). Start-ups may therefore struggle to attract the necessary financial capital. Incubators can contribute to the financial capital of start-ups by providing seed capital in exchange for equity, or they can help start-ups in an indirect manner to find external investments by connecting start-ups to external funding sources (Costa-David et al., 2002)

\subsubsection{Intangible resources}

- Knowledge can be defined and measured in many different ways (Grant, 1996; Quintane et al., 2011). We follow Scillitoe and Chakrabarti (2010) and Sullivan and Marvel (2011), who distinguish between technological and business knowledge. Start-ups are often founded by entrepreneurs with a technological background, which gives start-ups a solid technological knowledge 
Table 1

Start-up resource needs and incubator support.

\begin{tabular}{ll}
\hline Resource needs & Incubator support to fulfill resource needs \\
\hline Physical capital & - Office space \\
& - University equipment and library \\
Financial capital & - Seed capital in exchange for equity \\
& - Access to investors \\
Knowledge & - Provide technological knowledge through proximity to \\
& - University groups and laboratories \\
Social capital & - Facilitate the creation of external networks by organizing \\
& - Fents, creating partnerships and making introductions \\
& - Facilitate the creation of a community through co-location, \\
& social events and introductions \\
Legitimacy & Association with an established incubator
\end{tabular}

base (Oakey, 2003; Sullivan and Marvel, 2011). However, because these founders often lack managerial and entrepreneurial experience, business knowledge in start-ups tends to be underdeveloped (ibid). Incubators can contribute to the start-up's business knowledge by providing training programs or coaching by experienced entrepreneurs in the incubator (Rice, 2002). Training sessions, for example on sales or marketing, typically provide general knowledge. Coaching sessions can provide knowledge that is tailored to the start-up's situation, as coaches can engage in an ongoing dialogue with the entrepreneur and provide specific feedback (Chrisman et al., 2005; Rotger et al., 2012). University affiliated incubators may also add to a startup's technological knowledge base, as the proximity to university laboratories and research groups offers easier access to technological knowledge, thereby facilitating the technology transfer process (Etzkowitz, 2002; Rubin et al., 2015).

- Social capital refers to the ability of actors to extract benefits from their social structures, networks, and memberships (Davidsson and Honig, 2003). Such networks can provide 'social access' to resources controlled by others and can therefore be regarded as a substitute for resources that the actor itself does not own (Adler and Kwon, 2002; Borgatti and Foster, 2003). Accordingly, social capital is seen as a key resource for start-ups to access missing resources (Hite and Hesterly, 2001; Stam et al., 2014). However, because start-ups have not yet had time to build stable relationships and trust with others, they suffer from a lack of social capital (Hughes et al., 2007; Stinchcombe, 1965). An incubator with an established network can therefore provide substantial benefits by acting as a mediator to connect start-ups to external stakeholders (Bergek and Norrman, 2008; Soetanto and Jack, 2016). Incubators thereby enable start-ups to connect to venture capitalists, local governments, potential clients, or service providers. Incubators can facilitate such networks by organizing networking events, by creating partnerships with for example universities or investors, or through incubator managers who leverage their personal network (Hansen et al., 2000; Patton and Marlow, 2011). In addition to the incubator's 'external network', start-ups can also benefit from interacting with each other (the incubator's 'community') as they often struggle with similar problems (Hughes et al., 2007). Incubators may encourage such peer-to-peer interaction by co-locating start-ups in the incubator's shared office, by organizing social events or by making introductions (Cooper et al., 2010).

- Legitimacy refers to an organization's "right to exist and perform an activity in a certain way" (Bruton et al., 2010 p. 427). Obtaining legitimacy is necessary for organizations to attract other resources, such as social and financial capital (Bruton et al., 2010; Shane and Cable, 2002). Start-ups suffer from a lack of legitimacy as they do not have a track record or an established network (Aldrich and Fiol, 1994; Bruton et al.,
2010; Singh et al., 1986). To overcome this, start-ups can benefit from the legitimacy of others by creating partnerships or associations with more reputable organizations (Rao et al., 2008). Consequently, start-ups can gain legitimacy by being associated with or selected by an incubator that has a proven track record of supporting successful businesses, or that is itself affiliated with a reputable organization, such as a renowned university (Bøllingtoft and Ulhøi, 2005; McAdam and McAdam, 2008).

\subsection{Incubator intervention: assertiveness}

While the aforementioned resources have been identified as being important to start-ups, incubators can only help start-ups when start-ups actually use these resources. Recently, the RBV has seen a growing interest in the question of how firms obtain the necessary resources (Barney et al., 2011), a process that Sirmon et al. (2007) refer to as 'structuring' of the resource base. To successfully structure their resource base, firms continuously assess the resources in their possession, the resources they need to achieve their goals, and the subsequent resource 'gaps' that need to be addressed (Brush et al., 2001; Ireland, 2003). Then, firms engage in 'accumulating' (internal development of resources), 'acquiring' (external purchasing of resources) and 'divesting' (the shedding of obsolete resources) (Sirmon et al., 2007). While structuring their resource base, firms face difficult trade-offs. Accumulating or acquiring resources means that firms need to invest time and financial capital. As firms in general, and start-ups in particular, do not have unlimited means to fill all resource gaps simultaneously, they need to prioritize which resources to develop first (Brush et al., 2001; Sirmon et al., 2007). Incubators may choose to intervene in this process by stimulating or even forcing entrepreneurs to make use of the incubator's resources. In exploring how incubators can intervene in the incubation process, Bergek and Norrman (2008) distinguish between 'strong intervention' and 'laissez-faire' incubators. These two approaches differ on two dimensions: support intensity and the initiator of the support (entrepreneur or incubator).

Strong intervention incubators provide intense and pro-active support. Support may be provided by a large interdisciplinary team of incubator staff who are closely involved in the start-up's development (Clarysse et al., 2005). Such incubators can intervene through various practices. For example, incubators can engage in 'intense-aggressive' coaching (Rice, 2002) that may be mandatory for entrepreneurs to participate in (Patton et al., 2009). Incubators may also subject start-ups to an ongoing review process (Rice, 2002), with the incubator setting objectives or milestones that start-ups are required to achieve (Becker and Gassmann, 2006). Strong intervention incubators may even decide to replace the original founder by recruiting and installing experienced management teams (Clarysse et al., 2005). In contrast, laissez-faire incubators take a demand driven role and may only provide very few resources unless the entrepreneur explicitly asks for help. Consequently, support is provided on an ad-hoc basis to help entrepreneurs overcome a particular problem. The incubator staff may only consist of the incubator manager (Rice, 2002).

Bergek and Norrman (2008) see strong intervention and laissez faire incubators as two opposite ends of a scale. We refer to this scale as the incubator's assertiveness: more assertive incubators take a strong intervention approach, and less assertive incubators take a laissez-faire approach. We will build on the concept of incubator assertiveness to identify practices through which incubators intervene in the incubation process and stimulate startups to make use of the incubator's resources. 


\section{Methods}

\subsection{Research design and case description}

We conducted a qualitative multi case study. Such a qualitative approach is particularly suitable to understand the perceptions of actors (in our case, entrepreneurs and incubator staff) and allows us to gain rich and in-depth insights and develop new theory on the incubation of start-ups (Eisenhardt, 1989).

The incubators in our sample are all part of the Climate Knowledge and Innovation Community (Climate-KIC). Climate-KIC is an initiative of the European Institute of Innovation and Technology (EIT) and aims to accelerate the transition toward a sustainable society. Climate-KIC is one of three 'KICs', the independent operational parts of EIT that put the innovation agenda of EIT into practice. Every KIC consists of partners from all three sides of the 'knowledge triangle': research, higher education, and innovation-entrepreneurship-business (Climate-KIC, 2014). Climate-KIC has 12 academic partners, eight of which have an incubation program. Six incubators agreed to take part in this study. A detailed description of the sample incubators can be found in Table 2.

We selected this sample because it allows for comparison while maintaining a high level of variation, which contributes to the reliability and generalizability of our findings. Our sample is homogenous in the sense that all incubators focused on supporting start-ups in early stages of development and in technologybased industries. Further, all incubators were part of Europe's main initiative to promote innovative entrepreneurship and affililated with at least one university. Within these constraints, we maximized variation, which is particularly important when the population under study is heterogeneous, as is the case with incubators (Barbero et al., 2014; Pauwels et al., 2016). Incubators may provide a different mix of resources, depending on their specific industry focus (Baraldi and Havenvid, 2016; Schwartz and Hornych, 2008). Whereas start-ups in science based industries (such as life sciences or clean tech) require access to specialized equipment and technological knowledge, these resources may be superfluous for software start-ups. The supply and usage of the incubator's resources also depend on the start-up's development stage (McAdam and McAdam, 2008). For example, access to equipment may be particularly valuable when start-ups are developing a prototype, whereas access to customers through the incubator's network becomes increasingly important when startups are making first sales. Our sample captures this variety by including incubators supporting start-ups in different (technologybased) industries and in different (early) stages of development. Consequently, the incubators supported start-ups with different resources and levels of assertiveness, which enabled us to explore relationships between these concepts.

\subsection{Data collection}

We primarily gathered data through semi-structured interviews that were conducted between January and May 2012. We interviewed both entrepreneurs and incubator managers or staff to explore differences in perceptions regarding the resource needs of start-ups and to explore the assertiveness of incubators. We also interviewed local investors and technology transfer officers (TTOs) of the affiliated university to provide additional insights and allow for triangulation. All incubators were visited for a period ranging between 1 and 14 days to conduct face-to-face interviews on-site. This enabled us to augment the interview data with observations and informal discussions. If possible, we complemented the data with written documents, such as annual reports, mission statements, and policy documents. Multiple individuals were interviewed within each incubator to minimize personal bias. Together with the manager of each incubator, we selected a group of entrepreneurs to be approached for an interview that we felt was representative (in terms of maturity, sector, and background of entrepreneurs) of the particular incubator. Incubator managers could have obstructed the reliability of this study by only appointing entrepreneurs who were known to be content with the incubator's support. The relatively large number of interviews conducted across multiple cases minimized the possibility of this bias occurring. Further, the data indeed shows differences between the incubator's and entrepreneur's perceptions, which suggests that this bias did not occur or that its influence was at least minimal.

The interviews were structured as follows. We first asked entrepreneurs to introduce themselves and their start-up. We asked incubator staff to introduce themselves and the incubator. The core of the interviews then focused on the resource needs of start-ups, the resources with which start-ups were supported, and the assertiveness of the incubator. We asked both incubator staff and entrepreneurs about their perceptions regarding the resource needs of start-ups. We asked entrepreneurs to discuss why they joined the incubator (i.e., which particular resources they were looking for). This reflected their 'expected resource needs'. We then asked entrepreneurs to reflect on their stay in the incubator and identify ex-post the incubator's resources that had been most valuable to their start-up. This reflected their 'experienced resource needs'. We asked incubator staff to identify the most important resources that start-ups in their incubator were lacking (labelled as 'observed resource needs'). The semi structured nature of the interviews enabled the interviewees to explain their answers and to identify resources or other important characteristics in addition to our theoretical framework. Interviews with entrepreneurs and incubator staff took, on average, 30 and $40 \mathrm{~min}$, respectively. All interviews were digitally recorded and transcribed verbatim within three days. After every incubator visit, the interview scheme was reviewed and adjusted if the interviews revealed important information and concepts that were not yet included. Within each case, data were collected until no new concepts emerged and theoretical saturation was reached (Glaser and Strauss, 1967). Appendices B and C contain the final interview schedules that evolved over the interviews.

We conducted a total of 66 interviews. Due to time and practical constraints, we only conducted six interviews at incubator $\mathrm{F}$. However, as this particular incubator is a publicly listed company, more written documents were available, which compensated for the relatively small number of interviews.

We interviewed a diverse sample of 41 entrepreneurs (see Appendix A). Their start-ups were active in different industries and were in different stages of development. The age of incubated entrepreneurs differed between incubators; in some incubators, the majority was recent university graduates, whereas for others, entrepreneurs typically joined the incubator after they gathered substantial work or research experience. Next to a university affiliation, three incubators had partnered with research institutes or large technology-based companies. Given that a large part of the incubated entrepreneurs connected to the incubator through the incubator's partners, it is not surprising that 34 out of 41 interviewed entrepreneurs had a technical education (e.g., mechanical engineering, biomedical sciences or environmental sciences). 7 entrepreneurs had prior entrepreneurial experience; 34 entrepreneurs were first-time entrepreneurs.

\subsection{Data analysis}

To explore differences in perceived resource needs, a distinction was made prior to analysis between data coming from entrepreneurs and data coming from incubator staff. Entrepreneurs who were incubated at the time of the interview as well as graduates and entrepreneurs who did not yet participate (fully) in the incubation program were labelled as 'entrepreneurs.' Incubator 
Table 2

Characteristics of sample incubators

\begin{tabular}{|c|c|c|c|c|c|c|c|c|c|}
\hline Incubator & Country & Size & $\begin{array}{l}\text { Age } \\
\text { (years) }\end{array}$ & Background & Start-up development stages & Resources provided & Incubator assertiveness & $\begin{array}{l}\text { Industry } \\
\text { focus }\end{array}$ & $\begin{array}{l}\text { Interviews } \\
\text { conducted }\end{array}$ \\
\hline A & The Netherlands & $\begin{array}{l}\text { Incubator team of } \\
6 \text { employees } \\
\text { The incubator } \\
\text { premises houses } \\
55 \text { firms }\end{array}$ & 7 & $\begin{array}{l}\text { The incubator was established as a } \\
\text { nonprofit by the local government } \\
\text { and university }\end{array}$ & $\begin{array}{l}\text { Start-ups enter the two-year } \\
\text { 'incubation' phase when their } \\
\text { business plan is still develop- } \\
\text { ing. Start-ups have no sales or } \\
\text { funding. At the end of the in- } \\
\text { cubation period, start-ups have } \\
\text { typically raised capital, are } \\
\text { making sales and have hired } \\
\text { employees. Start-ups then en- } \\
\text { ter the 'growth' phase }\end{array}$ & $\begin{array}{l}\text { The incubator provides } \\
\text { office space, financial } \\
\text { support (as a loan), a } \\
\text { community, an external } \\
\text { network, coaching and } \\
\text { training }\end{array}$ & $\begin{array}{l}\text { During the incubation phase, } \\
\text { participation in the training ses- } \\
\text { sions is mandatory (strong } \\
\text { intervention) } \\
\text { During the growth phase, sup- } \\
\text { port is only provided on the } \\
\text { request of entrepreneurs (lais- } \\
\text { sez-faire) }\end{array}$ & $\begin{array}{l}\text { Software } \\
\text { Clean tech } \\
\text { Life } \\
\text { sciences }\end{array}$ & $\begin{array}{l}\text { Manager A1 } \\
\text { Manager A2 } \\
\text { Staff A3 } \\
\text { Staff A4 } \\
\text { TTO A5 } \\
\text { TTO A6 } \\
\text { TTO A7 }\end{array}$ \\
\hline B & The Netherlands & $\begin{array}{l}\text { Incubator team of } \\
4.5 \text { employees } \\
\text { The incubator } \\
\text { premises houses } \\
35 \text { firms }\end{array}$ & 3 & $\begin{array}{l}\text { The incubator was established as a } \\
\text { nonprofit through the merger of } \\
\text { several entrepreneurship programs } \\
\text { that were related to local institutes } \\
\text { for higher education }\end{array}$ & $\begin{array}{l}\text { Start-ups enter the six month } \\
\text { 'pressure cooker' phase when } \\
\text { the business plan is still devel- } \\
\text { oping. Start-ups have no sales } \\
\text { or funding. Start-ups then en- } \\
\text { ter the 'incubation' phase: the } \\
\text { business plan is stable and } \\
\text { start-ups are working towards } \\
\text { making sales }\end{array}$ & $\begin{array}{l}\text { The incubator provides } \\
\text { office space, financial } \\
\text { support (as a loan), a } \\
\text { community, an external } \\
\text { network, coaching and } \\
\text { training }\end{array}$ & $\begin{array}{l}\text { Start-ups have to meet specific } \\
\text { milestones during the pressure } \\
\text { cooker phase (strong } \\
\text { intervention). } \\
\text { In the incubation phase, support } \\
\text { is only provided on the request of } \\
\text { entrepreneurs (laissez-faire) }\end{array}$ & $\begin{array}{l}\text { Software } \\
\text { Life } \\
\text { sciences } \\
\text { Clean tech }\end{array}$ & $\begin{array}{l}\text { Manager B1 } \\
\text { Manager B2 } \\
\\
\text { Staff B3 } \\
\text { Staff B4 } \\
\text { TTO B5 } \\
\text { Investor B6 } \\
\text { Investor B7 }\end{array}$ \\
\hline c & Switzerland & $\begin{array}{l}\text { Incubator team of } \\
2 \text { employees }\end{array}$ & 5 & $\begin{array}{l}\text { The incubator was established as a } \\
\text { nonprofit organization by philan- } \\
\text { thropic (private) foundations in } \\
\text { cooperation with universities }\end{array}$ & $\begin{array}{l}\text { Entrepreneurs apply with an } \\
\text { idea. There is a very basic } \\
\text { business plan, no sales or } \\
\text { funding, and the start-up has } \\
\text { not incorporated yet. The in- } \\
\text { cubation program lasts nine } \\
\text { months, after which start-ups } \\
\text { should be ready to raise money }\end{array}$ & $\begin{array}{l}\text { The incubator does not } \\
\text { provide office space. Start- } \\
\text { ups gain access to coach- } \\
\text { ing and a support net- } \\
\text { work, and receive financial } \\
\text { support (as a grant) }\end{array}$ & $\begin{array}{l}\text { Start-ups have to achieve specific } \\
\text { milestones during the program. } \\
\text { The incubator also engages in } \\
\text { aggressive coaching sessions } \\
\text { (strong intervention) }\end{array}$ & $\begin{array}{l}\text { Software } \\
\text { Clean tech }\end{array}$ & $\begin{array}{l}\text { Manager C1 } \\
\text { TTO C2 } \\
\text { TTO C3 }\end{array}$ \\
\hline $\mathrm{D}$ & France & $\begin{array}{l}\text { Incubator team of } \\
7 \text { employees } \\
\text { The incubator } \\
\text { premises houses } \\
40 \text { firms }\end{array}$ & 12 & $\begin{array}{l}\text { The incubator was established as a } \\
\text { nonprofit by local educational in- } \\
\text { stitutions, research institutions and } \\
\text { multinational companies }\end{array}$ & $\begin{array}{l}\text { Start-ups enter the two-year } \\
\text { 'incubation' phase when their } \\
\text { business plan is still develop- } \\
\text { ing. At this point, start-ups } \\
\text { have no sales or funding. At the } \\
\text { end of the incubation period, } \\
\text { start-ups enter the 'post in- } \\
\text { cubation phase', and have ty- } \\
\text { pically raised capital, are mak- } \\
\text { ing sales and have hired } \\
\text { employees }\end{array}$ & $\begin{array}{l}\text { The incubator provides } \\
\text { office space, financial } \\
\text { support (as a loan), a } \\
\text { community, an external } \\
\text { network, coaching and } \\
\text { training }\end{array}$ & $\begin{array}{l}\text { In the incubation phase, the in- } \\
\text { cubator engages in aggressive } \\
\text { coaching. The incubator also re- } \\
\text { quires start-ups to participate in } \\
\text { training sessions and to meet } \\
\text { specific milestones (strong } \\
\text { intervention). } \\
\text { In the post-incubation phase, } \\
\text { support is only provided on the } \\
\text { request of entrepreneurs (lais- } \\
\text { sez-faire) }\end{array}$ & $\begin{array}{l}\text { Software } \\
\text { Clean tech } \\
\text { Life } \\
\text { sciences }\end{array}$ & $\begin{array}{l}\text { Manager D1 } \\
\text { Manager D2 }\end{array}$ \\
\hline $\mathrm{E}$ & The Netherlands & $\begin{array}{l}\text { Incubator team of } \\
1.5 \text { employees }\end{array}$ & 2 & $\begin{array}{l}\text { The incubator was established as a } \\
\text { nonprofit through the merger of } \\
\text { several start-up programs that } \\
\text { were related to local governments } \\
\text { and educational institutes }\end{array}$ & $\begin{array}{l}\text { The incubator supports pro- } \\
\text { jects from a very early 'idea' } \\
\text { stage up to established SMEs }\end{array}$ & $\begin{array}{l}\text { The incubator does not } \\
\text { provide office space. Fi- } \\
\text { nancial support is pro- } \\
\text { vided as a loan. Start-ups } \\
\text { also receive access to a } \\
\text { support network }\end{array}$ & $\begin{array}{l}\text { The incubator provides support } \\
\text { only on the request of en- } \\
\text { trepreneurs (laissez-faire) }\end{array}$ & $\begin{array}{l}\text { Agro / food } \\
\text { Chemicals } \\
\text { Life } \\
\text { sciences }\end{array}$ & $\begin{array}{l}\text { Manager E1 } \\
\text { Staff E2 } \\
\text { Staff E3 } \\
\text { TTO E4 }\end{array}$ \\
\hline $\mathrm{F}$ & United Kingdom & $\begin{array}{l}\text { Incubator team of } \\
3 \text { employees } \\
\text { The incubator } \\
\text { premises houses } \\
17 \text { firms }\end{array}$ & 6 & $\begin{array}{l}\text { The incubator was established as a } \\
\text { for profit organization by a uni- } \\
\text { versity in cooperation with a (uni- } \\
\text { versity related) investor and tech- } \\
\text { nology commercialization company }\end{array}$ & $\begin{array}{l}\text { At the research and idea phase, } \\
\text { a start-up is created around a } \\
\text { technological idea. Once the } \\
\text { 'business plan is agreed' and } \\
\text { start-ups have raised capital, } \\
\text { the start-up may move into the } \\
\text { incubator premises. }\end{array}$ & $\begin{array}{l}\text { Funding is provided in } \\
\text { exchange for equity. The } \\
\text { incubator provides office } \\
\text { space, a community, an } \\
\text { external network }\end{array}$ & $\begin{array}{l}\text { At the idea phase, an experienced } \\
\text { management team is often re- } \\
\text { cruited (strong intervention). } \\
\text { Once moved into the incubator, } \\
\text { the incubator provides support } \\
\text { on the request of en- } \\
\text { trepreneurs (laissez-faire) }\end{array}$ & $\begin{array}{l}\text { Life } \\
\text { sciences } \\
\text { Clean tech } \\
\text { Chemicals }\end{array}$ & $\begin{array}{l}\text { Manager F1 } \\
\text { TTO F2 }\end{array}$ \\
\hline
\end{tabular}


management, incubator staff, and TTOs or investors affiliated with the incubator were labelled as being part of the incubator. Data analysis was done using NVivo, a qualitative data analysis software program, and proceeded in multiple steps.

To answer our first research question, we explored the start-up's resource needs as perceived by entrepreneurs and incubator staff. We did so by categorizing the expected, experienced and observed needs according to the various tangible and intangible resources that were identified in Section 2.1. We then re-read the interview transcripts to inductively identify concepts that could explain differences in expected, experienced and observed needs. We initially identified concepts by using open coding (Corbin and Strauss, 1990). We labelled segments with 'in vivo' terms used by the interviewee to minimize researcher subjectivity and bias. We then combined similar open codes into 'first order categories' (Gioia et al., 2012) that were still labelled by staying close to the interviewees' own words. As coding continued, we started combining first order codes into broader, mutually exclusive and theoretically relevant 'second order categories' (Gioia et al., 2012) that provided a comprehensive explanation for the differences in expected, experienced and observed resource needs. The third phase of data analysis focused on the incubator's assertiveness, and was aimed at answering our second research question by identifying practices through which incubators intervene in the incubation process. Again, we initially relied on open and first order codes to allow distinctive incubation practices to emerge from the data. We then related these practices to the broader second order codes 'strong intervention' and 'laissez-faire' that were identified in our theoretical framework. By doing so, we were able to identify incubator practices that were both grounded in our empirical data and in our theoretical framework. As core categories emerged that explained the differences in perceptions and assertiveness, we turned to 'axial coding' (Corbin and Strauss, 1990) to explore relationships between our interpretations. This was the fourth phase of data analysis. The observation that entrepreneurs' expected and experienced needs differed made us realize that entrepreneurs' perceptions about the importance of resources change over time, which led us to explore if and how incubator assertiveness changes over time.

Throughout the data analysis process, we discussed emerging interpretations and findings with entrepreneurs and incubator staff to ask for feedback and to validate our findings. Such 'member validation' (Lincoln and Guba, 1986) increased the reliability of our findings.

\section{Findings}

The first part of this section identifies the start-up's resource needs as perceived by entrepreneurs and incubators, and explores (in)consistencies between these perceptions. The second part of this section explores the assertiveness of the incubator.

\subsection{Start-up needs and incubator support: resources}

\subsubsection{Descriptive results}

Table 3 gives an overview of the resources identified in the theory section and the extent to which entrepreneurs and incubator staff perceive them as needs of start-ups. We are aware that it is unconventional to quantify qualitative data. Given our relatively large interview sample, the purpose of Table 3 is merely to provide an overview of resource needs mentioned by entrepreneurs and incubators. For the remainder of our paper we will rely on the qualitative insights obtained through interviews.

- Expected resource needs. The most important reason for entrepreneurs in our sample to join the incubator was to access tangible resources (i.e. physical capital and financial capital). This is in
Table 3

Start-ups' resource needs as perceived by entrepreneurs and incubator staff. The numbers indicate how often each resource was mentioned during the interviews (interviewees could identify multiple resources).

\begin{tabular}{|c|c|c|c|c|}
\hline & & \multicolumn{2}{|c|}{ Entrepreneurs } & \multirow{2}{*}{$\begin{array}{l}\begin{array}{l}\text { Incubator } \\
\text { staff }\end{array} \\
\begin{array}{l}\text { Observed re- } \\
\text { source needs }\end{array}\end{array}$} \\
\hline & & $\begin{array}{l}\text { Expected } \\
\text { resource } \\
\text { needs }\end{array}$ & $\begin{array}{l}\text { Experienced } \\
\text { resource needs }\end{array}$ & \\
\hline \multicolumn{5}{|c|}{ Tangible resources } \\
\hline Financial ca & pital & 16 & 8 & 3 \\
\hline Physical ca & ital & 14 & 7 & 2 \\
\hline \multicolumn{5}{|c|}{ Intangible resources } \\
\hline \multirow[t]{2}{*}{ Social capital } & $\begin{array}{l}\text { External } \\
\text { network }\end{array}$ & 4 & 15 & 1 \\
\hline & Community & 3 & 19 & - \\
\hline \multirow[t]{2}{*}{ Knowledge } & $\begin{array}{l}\text { Business } \\
\text { knowledge }\end{array}$ & 4 & 24 & 12 \\
\hline & $\begin{array}{l}\text { Technological } \\
\text { knowledge }\end{array}$ & 2 & 1 & 2 \\
\hline Legitimacy & & 1 & 1 & 2 \\
\hline Total & & 44 & 75 & 22 \\
\hline
\end{tabular}

line with previous studies (e.g. McAdam and McAdam, 2008; Soetanto and Jack, 2013). Thirteen entrepreneurs were not consciously looking for any specific resources. They came from a parent organization (often a university) that was a partner of the incubator, which made joining the incubator an 'obvious' decision: "When you start a new company from this university, this incubator is a pretty obvious choice. All the well-known and successful examples come from this incubator" (Entrepreneur A4).

- Experienced resource needs. When reflecting on the most important resources provided by the incubator, entrepreneurs primarily identified business knowledge (developed through coaching or training), since they lacked this resource due to their technical background and lack of entrepreneurial experience. The incubator's community and external network were also identified as important resources. The incubator's community was mainly used to exchange business knowledge. Due to the broad industry focus of incubators in our sample, interviewees felt that the potential to exchange technological knowledge within the incubator community was limited. However, entrepreneurs emphasized that they experienced similar business-related challenges: "Everybody has to deal with customers, the business plan, sales, strategy, the bank, legal challenges. So it's very useful to talk about these things, even if the product you're developing is totally different" (Entrepreneur B4). The incubator's external network was particularly valued when it enabled entrepreneurs to access business knowledge through a network of specialized consultants: "What's also nice is access to the professional network of the incubator. (...) They have all kind of things: legal, IP, financing, tax, etcetera" (Entrepreneur F3).

- Observed resource needs. Incubator staff consistently identified business knowledge as the main resource need of start-ups. Incubators felt that, while entrepreneurs had a solid technological knowledge base, they did not know how to do sales, marketing, fundraising, pitching, etc. Accordingly, incubator staff felt that entrepreneurs lacked the necessary business knowledge to develop a business model around their technology or idea: "Selling their product, being able to clearly communicate their value proposition, that's a thing that a lot of entrepreneurs struggle with" (Incubator staff B3). This finding is in line with prior studies showing that technological entrepreneurs often lack the business experience that is necessary for the start-up to become successful (see Oakey, 2003; Vohora et al., 2004). 


\subsubsection{Comparison of perceptions}

Table 3 shows that, whereas the entrepreneur's expected needs focus on physical capital and financial capital, the incubator's observed needs focus on business knowledge. The interview data revealed several explanations for why entrepreneurs did not perceive the incubator's support to develop business knowledge as important, and why entrepreneurs were hesitant to make use of this resource.

Some of these explanations were related to the incubator and its resources. First, entrepreneurs may not use the incubator's resources when these resources are of insufficient quality. For example, entrepreneur B6 felt that the incubator manager "lacked experience". He therefore did not engage in the incubator coaching sessions, but preferred to consult with external mentors who had a more extensive entrepreneurial track record. A second explanation lies in the inability of incubators to tailor their resources to the specific needs of individual start-ups. Entrepreneurs found for example that the incubator lacked connections with industry partners to provide specialized knowledge. Third, we found that mature start-ups had already established a solid resource base, which rendered the incubator's support superfluous. Fourth, early stage start-ups with experienced entrepreneurs also had no need for the incubator's support, as entrepreneur E1 illustrated: "Most of the workshops organized by the incubator, we think that our experience exceeds the content. Don't forget, I've been an entrepreneur for 25 years. This is my fourth start-up". These four explanations all suggest that the incubator's resources are of insufficient quality, or that there is a mismatch between the incubator's supply and the start-up's demand for resources. Both explanations are in line with extant literature (Bruneel et al., 2012; Lalkaka, 2001; Ratinho and Henriques, 2010). Incubators tried to strengthen their resources (for example by attracting more experienced mentors) and they implemented selection processes that had to weed out start-ups that were too mature, start-ups outside the incubator's industry focus, or entrepreneurs that were too experienced. These selection processes had to ensure that the incubator only supported startups that could benefit from the incubator's services, although incubators were apparently not always able to achieve this goal.

Other explanations for the low usage of the incubator's resources to develop business knowledge were related to entrepreneurs and their (mis)perceptions about the resource needs of their start-up. Further inspection of Table 3 shows that the entrepreneurs' experienced needs are in line with the start-up's needs as observed by the incubator: both point at business knowledge, developed through training, coaching and the incubator's networks. The sharp contrast between incubators' observed resource needs and entrepreneurs' experienced resource needs on the one hand, and entrepreneurs' expected resource needs on the other hand is striking. In search of an explanation, the interview data revealed that, when joining the incubator, entrepreneurs were not aware of the incubator's potential to help develop business knowledge, nor were entrepreneurs willing to develop this resource. The data revealed three concepts that explain why, which we outlined with representative interview quotes in Table 4.

First, entrepreneurs not only lacked business knowledge, they were also not aware of its importance. In line with Oakey (2003), we found these inexperienced, technological entrepreneurs to have a 'technology push' view of invention, emphasizing technological development while underestimating the importance of satisfying a market need and creating a viable business model. Incubator manager E1 said that entrepreneurs were "unconsciously incompetent". Entrepreneurs had a lack of self-awareness: they were unable to recognize the gaps in the resource base of their start-up. Second, entrepreneurs were primarily short term oriented: they prioritized activities that yield immediate rewards. Activities such as writing a business plan, participating in sales seminars or building networks with peers and specialized

Table 4

Concepts that explain the differences between entrepreneurs' expected and experienced resource constraints.

\begin{tabular}{|c|c|c|}
\hline Second order codes & First order codes & Representative quote \\
\hline \multirow[t]{3}{*}{$\begin{array}{l}\text { Entrepreneurs unwilling to engage in the in- } \\
\text { cubation process to develop business } \\
\text { knowledge }\end{array}$} & $\begin{array}{l}\text { Entrepreneurs have a lack of self- } \\
\text { awareness }\end{array}$ & $\begin{array}{l}\text { "We call that unconsciously incompetence. Entrepreneurs don't know what } \\
\text { they don't know" (Incubator manager E1) } \\
\text { "I've been a first-time entrepreneur. There is a feeling that you can find at } \\
\text { almost all of them, that they know a lot of stuff (...) When you're a first-time } \\
\text { entrepreneur, often you don't have the connections, the knowledge of the } \\
\text { entrepreneur or the ecosystem. But you don't realize it" (Entrepreneur D4) } \\
\text { [about business activities] "You have to be aware of the importance of these } \\
\text { activities. But it takes time to get there... At first, you don't understand it... } \\
\text { Later, you start realizing that it's important" (Entrepreneur A5) }\end{array}$ \\
\hline & $\begin{array}{l}\text { Entrepreneurs are primarily short } \\
\text { term oriented }\end{array}$ & $\begin{array}{l}\text { "When you're an engineering startup, you have very little time to think. You } \\
\text { are basically sucked into details. Morning to evening, because you don't have } \\
\text { an assistant, you have to manage things by yourself. So (...) you tend to lose } \\
\text { sight of obvious priorities" (Entrepreneur D8)" } \\
\text { "During the daily business, entrepreneurs often forget to thoroughly think } \\
\text { about their business plan. Because they turn on their computer, and they got } \\
\text { an e-mail from a new customer, or they have to work on their website, etc. But } \\
\text { they're not doing what's most important-working on their business model or } \\
\text { their plan on how to enter the market." (Incubator staff B3) } \\
\text { "It's stuff that you need to do, but which is slightly less urgent than the rest, } \\
\text { and which tends to be delayed, and delayed" (Entrepreneur D8) }\end{array}$ \\
\hline & $\begin{array}{l}\text { Entrepreneurs are hesitant to step } \\
\text { out of their comfort zone }\end{array}$ & $\begin{array}{l}\text { "I think entrepreneurs in general, and starting entrepreneurs in particular, pay } \\
\text { not enough attention to sales. Instead, they go into their comfort zone. And } \\
\text { their comfort zone is the product or service they are developing. And being } \\
\text { vulnerable, exploring the marketing side, they often do not like this" (In- } \\
\text { cubator staff B3) } \\
\text { "Very early in the chain you need to expose yourself. Go out of your zone of } \\
\text { comfort, and talk to customers" (Incubator manager C1) } \\
\text { "We're working with high-tech startups, with students who are not familiar } \\
\text { with sales, financing (...). And they really hate those things" (Incubator } \\
\text { manager E1)“ }\end{array}$ \\
\hline
\end{tabular}


consultants do not create immediate value and, hence, can be easily neglected during the chaotic day-to-day business of a startup. Third, these technological entrepreneurs often did not feel comfortable going to sales seminars or writing a business plan, or simply did not enjoy participating in these activities. Incubator manager C1 said that entrepreneurs are hesitant to step out of their comfort zone, which refers to entrepreneurs' hesitance to engage in activities where they feel insecure or that they do not enjoy.

These three concepts point at the inability of incubated entrepreneurs to structure their resource base (Sirmon et al., 2007), as they are insufficiently aware of their resource gaps (Grant, 1991) and not willing to make the necessary (time) investment to develop missing resources. The image emerged that entrepreneurs joined the incubator to access tangible resources, initially being unwilling to engage in the incubation process to develop business knowledge. As shown in Table 3, entrepreneurs eventually recognize the importance of this resource when reflecting on their stay in the incubator. Entrepreneur B1 illustrates how he only recognized the value of the incubator's resources ex-post: "In the beginning, I was like, "I have taken numerous business courses, how can these workshops help me?" (...) These workshops turned out to be very valuable (...) But initially, I really didn't see the point". Similarly, entrepreneur A5 felt that he initially undervalued the incubator's resources: "When we joined, we had no idea how valuable [the incubator] would turn out to be. We just thought it would be easy money". Accordingly, entrepreneurs become more aware of their resource needs and the value of the incubator's resources as the incubation process advances and their start-ups mature. Entrepreneur D4 felt that a lack of self-awareness is typical for firsttime entrepreneurs: "I've been a first-time entrepreneur. There is a feeling that you can find at almost all of them, that they know a lot of stuff (...) When you're a first-time entrepreneur, often you don't have the connections, the knowledge of the entrepreneur or the ecosystem. But you don't realize it". Incubator manager B1 supported this point, and felt that founders with entrepreneurial experience are typically more aware than first-time entrepreneurs: "We note that more experienced entrepreneurs make the most use of our services (...) These experienced guys see the opportunities that we offer them". These findings are in line with previous studies suggesting that it is primarily first-time founders of early-stage start-ups who are unaware of their needs and hesitant to ask for help (Brixy et al., 2013; Oakey, 2003; Patton, 2014; Vohora et al., 2004).

Our findings show that the low quality of the incubator's resources and the mismatch between demand and supply in resources, as stressed in extant literature (see Bruneel et al., 2012; Ratinho and Henriques, 2010), only partially explains the low usage of the incubator's resources. While some entrepreneurs indeed felt that the incubator's resources were not in line with their needs, Table 3 shows that a large number of entrepreneurs in our sample were satisfied with the incubator's resources, but initially not willing to use these resources due to the concepts outlined in Table 4. Incubators tried to select entrepreneurs who were willing to make use of the incubator's resources and aware of their resource gaps: entrepreneurs needed to be "coachable" (Incubator manager B1), "willing to learn" (Incubator manager A2) and "aware of what they're missing" (Incubator manager E1). However, despite such selection criteria, entrepreneurs were still hesitant to participate in coaching sessions, workshops or networking events: "too many entrepreneurs enter the building in the morning, go their office and lock the door" (Incubator staff B3). Consequently, we found incubators to implement various practices to stimulate entrepreneurs to make use of the incubator's resources, which we explore in the next section.

\subsection{Incubator intervention: assertiveness}

As shown in Table 2, the incubators that supported early stage start-ups took a strong intervention approach. These early stage start-ups were often founded by first-time entrepreneurs and had no funding, no sales, and a business plan that was still developing. Incubators took a strong intervention approach because, as shown in Section 4.1.2, such entrepreneurs struggle to recognize the resource gaps of their start-up and are hesitant to engage in the incubation process. Incubator manager B1 said: "Those who are completely new to entrepreneurship are the ones that sit in their offices with the door closed, and we need to stimulate them to participate in the program". Incubator manager A1 gave a similar argument: "We try our best to stimulate [entrepreneurs] to participate in the program, because it can be really valuable for them. But often, entrepreneurs initially do not see this value". Strong intervention incubators provided "pro-active and vigilant assistance" (incubator manager D1), using various practices to stimulate start-ups to make use of the incubator's resources (see Table 5).

First, incubators engaged in aggressive coaching sessions, which refers to incubator managers subjecting start-ups to a critical assessment. During such sessions, incubator managers asked critical questions about the start-ups' business plan: "a lot of questions that we couldn't answer" (Entrepreneur C5). This made entrepreneurs aware of the importance of business knowledge and the start-up's lack thereof. As such, the incubator identified the resource gaps that entrepreneurs were not aware of. Second, mandatory participation entails making attendance of training or coaching sessions a requirement for entrepreneurs to be admitted into the incubator. By doing so, incubators stimulated entrepreneurs to reflect on the resource gaps of their start-up and to develop missing resources. Accordingly, entrepreneurs were stimulated to step out of their comfort zone and address long-term challenges: "It's pretty tough when you're forced to leave your office for two or three days every six weeks. But it's very useful to take a step back once in a while, to take a strategic overview of your company. It forces you to think about stuff that is important but not yet urgent" (Entrepreneur A5). Third, milestone setting refers to incubators requiring start-ups to achieve specific targets or goals. Similar to mandatory participation, setting milestones stimulated entrepreneurs to develop and recognize the value of business knowledge, as many of these milestones were business-related. Entrepreneurs were for example required to write a business plan, to meet with a certain number of potential customers, or to find a launching customer. Fourth, entrepreneur recruitment refers to incubators searching and installing an experienced entrepreneur to replace the technological founder as CEO of the start-up. To do so, the incubator acts as an investor, providing large amounts of financial capital in return for an equity stake and a board seat. This position enabled the incubator to install a new CEO. This experienced CEO compensated for the technological founder's lack of business knowledge.

Through the above practices, the incubator takes a strong intervention approach, as it makes start-up aware of their resource gaps and stimulates start-ups to develop missing resources. While doing so may lead to better valuation and usage of the incubator's resources, there were also concerns about this approach. Some interviewees felt that the incubator had too much influence on the start-up's development. This could make start-ups too dependent on the incubator's guidance. Further, the incubator's guidance could be wrong, as incubator manager A1 said: "It requires a lot of experience. You risk pointing [the start-ups] in the wrong direction".

Section 4.1.2 showed how entrepreneurs become more aware of their resource needs and the value of the incubator's resources as the incubation process advances and their start-ups mature. This explains why all incubators in our sample that supported mature start-ups took a laissez-faire approach (see Table 2). Some incubators even made an 
Table 5

Incubator assertiveness.

\begin{tabular}{ll}
\hline $\begin{array}{l}\text { Second order codes (incubator } \\
\text { assertiveness) }\end{array}$ & $\begin{array}{l}\text { First order codes (incubator } \\
\text { practices) }\end{array}$
\end{tabular}

Strong intervention

Aggressive coaching

Mandatory participation

Fixed milestones

Entrepreneur recruitment

Laissez-faire
"The coaching sessions were very tough. We presented our ideas, and the coaches were just asking good questions. 'How will you make revenue? Who's going to buy it? Why? What is the competition? ' A lot of questions that we couldn't answer, because we approached our business in an academic way: we have an idea, the customer will be there. So it was very tough feedback" (Entrepreneur C5)

"It is people to prioritize, getting them out of their zone of comfort, being very blunt. Sometimes even aggressive some people might feel" (Incubator manager C1)

"We require our entrepreneurs to participate in the master class program if they want to enter the incubator. If they are not willing to, than we know that the entrepreneur does not know himself well enough, because we know that everyone needs it" (Incubator manager A1) "They demand that you attend the trainings. In my opinion, it's good. Especially for first-time entrepreneurs (...) If you want to be helped, they help you. If you don't want to be helped, they insist. And oblige you to go to training. Make some compulsory writings" (Entrepreneur D4) "You have between stage one and stage two three months. It's not you come back when you're ready. You come back in three months. What we look at is the ability of the entrepreneur to behave as an entrepreneur" (Incubator manager C1)

"The committee will see if they have met their targets, a predefined list of ten criteria, of which they have to achieve seven. If these targets are met, then they will join the program for about six months to one year. If not, then they'll have to leave the incubator" (Incubator manager B1) "We find really good management, and we pay them to get involved in these businesses (...) We create an immediate option for the manager to get a big slug from [the equity], and the business is all launched at the same time" (TTO F2).

"An academic is like an engineer who builds a ship. Although he might be an expert on how to build the ship, this doesn't mean that he is the right person to be the captain of this ship. You could then try to teach him how to sail, but we think it's more effective to hire an experienced captain" (Incubator manager F1)

"It's up to you to take initiative. We try to consciously ask ourselves 'what are things [the incubator] can help us with? "' (Entrepreneur A5)

explicit distinction between a strong intervention first phase (referred to as the 'pressure cooker' by incubator B), and a laissez-faire second phase of the incubation process (referred to as the 'growth phase' by incubator A). Incubator manager D1 said: "during the early phases of the company, the interaction is very intense. We tend to pull back gradually as companies mature". In this later phase, start-ups' business plans were mature and stable, start-ups had raised their first rounds of funding, and most start-ups were making sales and delivering products. Incubators supporting such mature start-ups worked demand driven. Incubators provided start-ups with access to resources, but it was up to the entrepreneur to identify the start-up's needs, to recognize the value of the incubator's resources, and to approach the incubator for support. The incubator's tendency to use a laissez-faire approach as the incubation process progresses reflected the start-up's development towards a mature and autonomous company. Start-ups relied less on the incubator, not only in terms of resource support, but also in terms of guidance and intervention. The incubator thereby prepares the start-up to leave the incubator. Incubator manager A2 said: "The first phase is more intense (...). As entrepreneurs and their companies mature, they start building their own network, and we also expect them to have their own advisory board after four or five years. So they become less dependent on our coaches".

\section{Discussion}

To explain the low usage of the incubator's resources, our study focused on the perceptions that entrepreneurs and incubator staff have about the importance of the incubator's resources. By doing so, our study provides important implications for incubation theory and practice.

\subsection{Theoretical implications}

Our paper makes two important contributions to the field of start-up and incubator research.

First, we provide a more comprehensive explanation for the low usage of the incubator's resources. Prior studies primarily pointed at the low quality of the incubator's resources and at a mismatch between the start-up's needs and the incubator's supply of resources (Bruneel et al., 2012; Totterman and Sten, 2005). While we confirm these findings, we also stress that they only provide a partial explanation. Our study identified an additional mismatch: a mismatch between the resources entrepreneurs want when they join the incubator, and the resources entrepreneurs need to complement their resource base. The cause for the latter mismatch is the inability of firsttime, early stage entrepreneurs to 'structure' their resource base. These entrepreneurs are unable to recognize their resource gaps and not willing to make the necessary investments in developing missing resources (Sirmon et al., 2007) because they are hesitant to step out of their comfort zone and short term oriented. This explains why these entrepreneurs may not use the resources provided by incubators, even when resources are of sufficient quality and in line with the start-up's needs. We thereby provide a partial explanation for why many incubators do not realize their potential.

If entrepreneurs struggle to identify their resource gaps and are not willing to make use of the incubator's resources, then having a valuable resource portfolio is a necessary but insufficient condition for incubators to help start-ups. Our second contribution lies in explaining how incubators can intervene to increase the usage of resources and in identifying the conditions under which incubators should do so. Incubators can increase the usage of resources by taking a strong intervention approach. Strong intervention incubators help start-ups to recognize their resource gaps 
and stimulate them to develop missing resources. We identified various practices through which incubators can implement a strong intervention approach. We thereby responded to calls for research on incubation practices (Ahmad and Ingle, 2013; Hackett and Dilts, 2004; Phan et al., 2005). We have shown that it is primarily first-time entrepreneurs with early stage start-ups who are not able to recognize their resource gaps and not willing to engage in the incubation process. Consequently, taking a strong intervention approach is particularly important when supporting earlystage start-ups founded by first-time entrepreneurs. Given that these entrepreneurs did seem to be aware of the value of tangible resources, strong intervention is required when providing intangible resources in general and business knowledge in particular. However, taking a strong intervention approach throughout the entire incubation process means that start-ups remain dependent on the incubator's resources and guidance. This may ultimately constrain the start-up's development towards an independent company. Further, our findings suggest that entrepreneurs become increasingly aware of their resource gaps and the value of the incubator's resources as the incubation process advances and their start-ups mature. This reduces the need for the incubator to take a strong intervention approach.

All in all, our findings move away from studies that see incubators merely as a resource rich environment (Albert and Gaynor, 2001; McAdam and McAdam, 2008). Our study points out that start-ups not only lack necessary resources, but also the willingness and ability to complement their resource base. If incubators only provide resources and guidance without addressing this skills gap, start-ups will likely fail as soon as they leave the incubator. Consequently, the incubator should be an environment where start-ups (a) learn how to identify gaps in their resource base, and (b) develop the willingness and ability to autonomously acquire or develop these resources. By doing so, incubators have the potential to provide start-ups with a competitive advantage that lasts beyond the incubation period.

\subsection{Practical implications}

We recommend incubators to provide entrepreneurs with the resources they need, which may be different from the resources entrepreneurs want. If intake interviews reveal that entrepreneurs are inexperienced, have a lack of self-awareness, are short term oriented and are not willing to step out of their comfort zone, we encourage incubators to take a strong intervention approach to create awareness among entrepreneurs and to ensure that they develop the correct resources. Incubators may use the practices that we identified as a guideline to implement such an approach.

For entrepreneurs, it is important to find an incubator that is in line with their needs. Inexperienced entrepreneurs should acknowledge that they not only need resources, but also guidance on which resources to develop (for example by engaging in reflective coaching). Entrepreneurs should be willing to ask for support and open to receiving feedback. In contrast, experienced entrepreneurs should realize that such an intense program will likely add little value, and they should therefore choose a laissez-faire incubator.

Our study also has important implications for policy makers. To improve the conditions for start-ups, scholars often advise policy makers to adapt their policies to the needs of start-ups by asking entrepreneurs what they perceive as the main factors constraining entrepreneurial activity (Carayannis et al., 2006; Stam, 2015). However, when entrepreneurs are not able to recognize their needs, such demand driven policies will likely be ineffective. Consequently, we caution policy makers for merely responding to the needs as perceived by inexperienced, technological entrepreneurs and we encourage them to at least complement these assessments with insights from more experienced entrepreneurs and other stakeholders. Also, rather than only providing resources, we encourage policies that aim more explicitly to provide entrepreneurs with the necessary skills to structure their resource base, such as entrepreneurship education programs.

\subsection{Limitations and suggestions for future research}

Our study has three main limitations that we encourage future studies to address.

First, the interviews with incubators and entrepreneurs were only conducted at one point in time. The mismatch between entrepreneurs' expected resource needs and their experienced resource needs calls for further longitudinal research to better understand how entrepreneurs' perceptions change over time. Such efforts could identify particular milestones in the start-up's development that intersect with a growing ability of the entrepreneur to recognize resource gaps and develop missing resources. These milestones would enable incubators to further tailor their support to individual start-ups.

Second, the particular characteristics of our sample need to be taken into account when interpreting and generalizing the results. The incubators in our sample were located in different countries. The importance of particular resources may depend on regional characteristics, and may therefore vary across our sample. We found some support for this. For example, physical capital was identified at incubator $\mathrm{F}$ as an important resource, as affordable office space in this particular region was scarce. Still, the importance of business knowledge and the entrepreneurs' misperceptions regarding this resource were consistently observed across all cases. We are therefore confident that our findings are not due to local contextual factors. Still, it would be interesting to expand our approach to incubators active in other regions. We also encourage future studies on incubators supporting more experienced entrepreneurs, since our findings may not apply to such incubators. Providing business knowledge may be less relevant to such incubators and they may not be required to take a strong intervention approach, since our findings suggest that experienced entrepreneurs are better aware of their resource gaps and the value of the incubator's resources. However, because the incubators in our sample tailored their services towards first-time entrepreneurs, further research is necessary to confirm this.

Third, we did not take the success of incubators into consideration. The question of how to measure incubator success is one of the most controversial debates in incubator research (Dee et al., 2011; Hackett and Dilts, 2004) and was outside the scope of this study. We encourage future studies to assess the incubator's output in general, and studies on the relationship between the incubator's assertiveness and its performance in particular. Such studies could test our hypothesis that the need for incubators to take a strong intervention approach declines as the incubation process advances and start-ups mature.

In addition to addressing these limitations, we suggest future studies to use two perspectives that can add promising insights, yet remain largely neglected in the context of incubator studies. First, given that our findings point at the importance of entrepreneur's ability to successfully acquire business knowledge during the incubation period, we encourage future studies to apply theories of 'organizational learning' (Cyert and March, 1963) to better understand how incubators help start-ups acquire new knowledge. Second, literature on 'entrepreneurial cognition' may be useful to better understand why entrepreneurs are unable to take advantage of incubators. Studies on entrepreneurial cognition find that entrepreneurs are more likely to display particular 'cognitive biases' in their decision making (Busenitz and Barney, 1997; Simon et al., 2000). Some of these biases echo the findings of our study, such as entrepreneurs' inability to recognize their own limitations (Simon et al., 2000) and their hesitance to invest 
in unfamiliar resources (Garbuio et al., 2011). Our study suggests that such biases may limit the impact of policy measures, such as incubators. Consequently, we encourage future studies to apply literature on entrepreneurial cognition to explore the cognitive biases of incubated entrepreneurs in more detail.

\section{Conclusion}

We explored entrepreneur's and incubator staff's perceptions about the importance of the incubator's resources. We also explained differences in perceptions and the implications of these differences for incubators. We have shown that entrepreneurs and incubator staff both perceive business knowledge, developed through training, coaching or networks, as the incubator's most valuable resource. However, entrepreneurs primarily join the incubator to access physical capital and financial capital and are initially hesitant to engage in the incubation process to develop business knowledge. The reason for this is that early stage, first-time incubated entrepreneurs are 'unconsciously incompetent'; they are not aware of their resource gaps or the importance of business knowledge. In addition, they are unwilling to engage in the incubation process to develop this resource. This is because doing so requires entrepreneurs to step out of their comfort zone, and because entrepreneurs are primarily short-term oriented. As entrepreneurs gain experience in developing business knowledge, they recognize its importance and are thus better able to utilize the incubator's resources. In response to the changing perceptions of entrepreneurs, we found incubators to pursue different levels of assertiveness. When entrepreneurs were inexperienced and did not prioritize developing business knowledge, incubators took a strong intervention approach in which they identify the start-up's resource gaps, and stimulate start-ups to develop missing resources. Incubators did so by engaging in aggressive coaching, by setting milestones, by making participation mandatory or by recruiting experienced management. As start-ups mature and entrepreneurs eventually recognize the importance of business knowledge, incubators were found to take a laissez-faire approach. This prepared start-ups to leave the incubator.

\section{Acknowledgements}

This study was supported by the Climate Knowledge and Innovation Community, which is part of the European Institute of Innovation and Technology.

\section{Appendix A. : characteristics of sample start-ups}

\begin{tabular}{|c|c|c|c|c|c|}
\hline Incubator & Entrepreneur & Start-up industry & $\begin{array}{l}\text { Start-up age } \\
\text { (years) }\end{array}$ & $\begin{array}{l}\text { First-time } \\
\text { entrepreneur }\end{array}$ & $\begin{array}{l}\text { Technological formal } \\
\text { education }\end{array}$ \\
\hline \multirow[t]{7}{*}{ A } & A1 & Software: social platform & 2 & Yes & No \\
\hline & A2 & Software: security & 4 & Yes & Yes \\
\hline & A3 & Maritime technology & 5 & Yes & Yes \\
\hline & A4 & $\begin{array}{l}\text { Clean tech: energy } \\
\text { production }\end{array}$ & 1 & Yes & Yes \\
\hline & A5 & $\begin{array}{l}\text { Clean tech: energy } \\
\text { production }\end{array}$ & $<1$ & Yes & Yes \\
\hline & A6 & Maritime technology & 2 & Yes & Yes \\
\hline & A7 & $\begin{array}{l}\text { Clean tech: energy } \\
\text { production }\end{array}$ & 2 & Yes & Yes \\
\hline \multirow[t]{7}{*}{ B } & B1 & Life sciences: software & 2 & No & Yes \\
\hline & B2 & Telecommunications & $<1$ & Yes & No \\
\hline & B3 & Life sciences: diagnostics & $<1$ & Yes & Yes \\
\hline & B4 & $\begin{array}{l}\text { Clean tech: energy } \\
\text { production }\end{array}$ & $<1$ & Yes & Yes \\
\hline & B5 & Software: social platform & $<1$ & Yes & No \\
\hline & B6 & Software: social platform & 1 & No & Yes \\
\hline & B7 & Software: social platform & $<1$ & Yes & No \\
\hline \multirow[t]{8}{*}{ C } & $\mathrm{C} 1$ & Software: social platform & $<1$ & Yes & Yes \\
\hline & $\mathrm{C} 2$ & Clean tech: energy efficiency & 2 & Yes & No \\
\hline & $\mathrm{C} 3$ & Software: social platform & $<1$ & Yes & Yes \\
\hline & $\mathrm{C} 4$ & Clean tech: energy efficiency & 3 & Yes & Yes \\
\hline & $\mathrm{C} 5$ & Clean tech: energy efficiency & 3 & Yes & Yes \\
\hline & C6 & Clean tech: energy efficiency & 3 & Yes & Yes \\
\hline & $\mathrm{C} 7$ & $\begin{array}{l}\text { Clean tech: energy } \\
\text { production }\end{array}$ & 3 & No & No \\
\hline & $\mathrm{C} 8$ & Life sciences: biotech & 1 & Yes & Yes \\
\hline \multirow[t]{6}{*}{$\mathrm{D}$} & D1 & $\begin{array}{l}\text { Clean tech: energy } \\
\text { production }\end{array}$ & 2 & No & No \\
\hline & D2 & Software: security & 3 & Yes & Yes \\
\hline & D3 & Telecommunications & 6 & Yes & Yes \\
\hline & D4 & Life sciences: diagnostics & 2 & No & Yes \\
\hline & D5 & Telecommunications & 6 & Yes & Yes \\
\hline & D6 & Software: social platform & $<1$ & Yes & Yes \\
\hline
\end{tabular}




\begin{tabular}{|c|c|c|c|c|c|}
\hline & D7 & Software: social platform & $<1$ & Yes & Yes \\
\hline & D8 & Life sciences: software & $<1$ & Yes & Yes \\
\hline \multirow[t]{8}{*}{$\mathrm{E}$} & E1 & Life Sciences: biotech & 2 & No & Yes \\
\hline & E2 & Maritime technology & 7 & Yes & Yes \\
\hline & E3 & Life sciences: diagnostics & $<1$ & Yes & Yes \\
\hline & $\mathrm{E} 4$ & $\begin{array}{l}\text { Software: e - commerce } \\
\text { (food) }\end{array}$ & $<1$ & Yes & Yes \\
\hline & E5 & Agro & 2 & Yes & Yes \\
\hline & E6 & $\begin{array}{l}\text { Software: e - commerce } \\
\text { (food) }\end{array}$ & 2 & Yes & Yes \\
\hline & E7 & Agro & 2 & Yes & Yes \\
\hline & E8 & Life sciences: biotech & 2 & Yes & Yes \\
\hline \multirow[t]{3}{*}{$\mathrm{F}$} & $\mathrm{F} 1$ & Life sciences: diagnostics & 11 & Yes & Yes \\
\hline & $\mathrm{F} 2$ & Agro & 1 & No & Yes \\
\hline & F3 & Chemicals & 4 & Yes & Yes \\
\hline
\end{tabular}

\section{Appendix B. : interview questionnaire, incubator management} Introduction: incubator characteristics

1. Could you please state your name and your responsibilities within this incubator?

a. Are you also a personal mentor of some tenant firms?

b. Could you briefly describe your personal background (e.g., entrepreneurial experience)?

2. When was this incubator program established?

3. How many people work for the incubator (FTE)?

4. What is the annual budget of this incubator?

5. How many tenant firms are currently within the incubator?

a. How much employees (FTE) do they have (in total)?

6. Do you have an advisory board in place?

a. What is their role?

Problem: incubator necessity

1. Why do entrepreneurs need this incubator?

a. Why is it hard for entrepreneurs to succeed?

b. What are problems entrepreneurs struggle with?

2. How would you describe the general entrepreneurial climate in this country or region?

a. What are strengths or weaknesses (for example, government regulations, the status that society attaches to entrepreneurs, an overload of bureaucracy, etc.)?

b. How would you compare it with other (European) regions?

Aim: incubator success

We have now discussed the entrepreneurial climate of this region and various challenges that entrepreneurs struggle with. I assume that this incubator is a means to overcome these challenges.

1. What is your goal as an incubator? When would you consider yourself to be successful?

a. How do you measure your success?

i. Do you often measure your success and compare it with your peers?

ii. Is there an agreed definition of this incubator's success?

2. Can you tell me anything about postexit performance of the tenant firms?

3. Do you measure your survival rate?

a. If yes, what was your survival rate last year (measured as the

total number of tenant firms divided by the number of tenant firms that quit their business)?

Solution: incubator support

Now that we have addressed both the issues entrepreneurs struggle with as well as your mission to help them overcome these problems, I would like to talk about how you support the entrepreneurs. 
1. What kind of support do you offer to tenant firms (for example,

linking tenant firms to experienced entrepreneurial mentors, offering tenant firms an extensive network, etc.)?

a. What form/forms of support do you think is/are most important?

b. What do you receive/expect in return from tenant firms?

c. In what ways do you deliver this support (e.g., master classes, networking events, mentor sessions)?

1. *Based on the answers given to the previous question, check if the use of the following types of resources have been discussed and how valuable they are for tenant firms.*
a. Physical capital
i. Basic: office space, administrative services
ii. Specialized: laboratories, libraries
b. Financial capital: investments, start-up capital, loans
c. Human capital: training programs, master classes, education
d. Knowledge

i. Business skills (mentor/coach)

1.

How many firms is each individual mentor assigned to?

ii. Scientific knowledge (role university)

a. Social capital:

i. Community

ii. External networking

a. Reputation

2. Is there any form of support that is offered to tenant firms but is not used?

3. What do you think is most important in your range of support services?

Other

1. What does the university do to stimulate students and academic staff to engage in entrepreneurial activities?

2. Let's talk about the process by which you select the tenant firms.

a. Where are tenant firms coming from (e.g., mainly students or also outside university)?

b. How can potential tenant firms apply for a position inside the incubator?

c. Would you say you have a more entrepreneur-/ entrepreneurial team-focused approach or a more idea-focused approach?

d. What percentage is accepted?

3. Does the incubator specialize in a certain industry or sector?

a. To what extent is this incubator oriented toward clean-tech industry or clean-tech firms?

i.

What percentage of the current tenant firm portfolio operates in the clean-tech industry?

4. Would you recommend all start-ups to be supported by an incubator (either this one or another)?

a. Why or why not?

\section{Appendix C. : interview questionnaire, entrepreneurs}

\section{Introduction questions}

1. Can you state your name, company name, and your responsibilities within the company?

2. What is the basic product or service that the company delivers? 
Prior to Start-up (Background)

Let's go back to the point just before you started your current business.

1. Was there a link with the university?

a. Were you a student/PhD/professor?

2. Was this business the result of research at a university/research institution?

a. Did you feel like the university supported you during the venture creation process?

i.

Why or why not?

Joining the Incubator (Perceived needs)

1. What was your main motive to apply for a position at this incubator?

a. What were problems/challenges you struggled with?

2. At what point during your business cycle did you apply for the incubator, and to what extent did you develop your business ideas/business plan?

Incubator Support (Experienced needs)

1. In what ways does the incubator support you and your business?

a. What is most important?

2. *Based on the answers given to the previous question, check if

the following types of resources have been addressed and how valuable they are for tenant firms.*

a. Physical capital

i. Basic: office space, administrative services

ii. Specialized: laboratories, libraries

b. Financial capital: investments, start-up capital, loans

c. Human capital: training programs, master classes, education

d. Knowledge

i. Business skills (mentor/coach)

ii. Scientific knowledge (role university)

e. Social capital

i. Community: other entrepreneurs

ii. External networking

f. Legitimacy: do you feel that being associated with the incubator brings certain credibility to your company?

3. We have now discussed various ways in which the incubator supports you and your venture.

a. First of all, is there any way in which the incubator supports you and your venture that we have not discussed during this interview?

b. Can you think of any way in which the incubator could support you more than it does right now?

c. Is there any kind of support which is offered to you that you do not make use of?

d. Does the incubator play a pro-active role, or do you mostly initiate the support process?

4. Looking back from the point where you and your business are right now, how important was the incubator to your success/development on a five-point scale?

a. Would you have started your business if it wasn't for the incubator?

\section{References}

Adler, P.P.S., Kwon, S.S.-W., 2002. Social capital: prospects for a new concept. Acad. Manag. Rev. 27, 17-40.

Aerts, K., Matthyssens, P., Vandenbempt, K., 2007. Critical role and screening practices of European business incubators. Technovation 27, 254-267.

Ahmad, A.J., Ingle, S., 2013. Business incubators and HTSF development: setting an agenda for further research. In: Oakey, R., Groen, A., Cook, C., Van Der Sijde, P. (Eds.), New Technology-Based Firms in the New Millenium, Volume 10t.
Emerald Group Publishing Limited, Bingley, pp. 119-140.

Albert, P., Gaynor, L., 2001. Incubators: growing up, moving out - a review of the literature. Cah. De. Rech., Arpent.

Aldrich, H., Fiol, C., 1994. Fools rush in? The institutional context of industry creation. Acad. Manag. Rev. 19, 645-670.

Amezcua, A.S., Grimes, M.G., Bradley, S.W., Wiklund, J., 2013. Organizational sponsorship and founding environments: a contingency view on the survival of 
business incubated firms, 1994-2007. Acad. Manag. J. 56, 1628-1654.

Amit, R., Schoemaker, P.J.H., 1993. Strategic assets and organizational rent. Strateg. Manag. J. 14, 33-46.

Baraldi, E., Havenvid, M.I., 2016. Identifying new dimensions of business incubation: a multi-level analysis of Karolinska Institute's incubation system. Technovation 50-51, 53-68.

Barbero, J.L., Casillas, J.C., Wright, M., Ramos Garcia, A., 2014. Do different types of incubators produce different types of innovations? J. Technol. Transf. 39, $151-168$.

Barney, J., 1991. Firm resources and sustained competitive advantage. J. Manag. 17, 99-120.

Barney, J.B., Ketchen, D.J., Wright, M., 2011. The future of resource-based theory: revitalization or decline? J. Manag. 37, 1299-1315.

Becker, B., Gassmann, O., 2006. Gaining leverage effects from knowledge modes within corporate incubators. R. D. Manag. 36, 1-16.

Bergek, A., Norrman, C., 2008. Incubator best practice: a framework. Technovation $28,20-28$.

Bøllingtoft, A., Ulhøi, J.P., 2005. The networked business incubator — leveraging entrepreneurial agency? J. Bus. Ventur. 20, 265-290.

Borgatti, S.P., Foster, P.C., 2003. The network paradigm in organizational research: a review and typology. J. Manag. 29, 991-1013.

Brixy, U., Sternberg, R., Stüber, H., 2013. Why some nascent entrepreneurs do not seek professional assistance. Appl. Econ. Lett. 20, 157-161.

Bruneel, J., Ratinho, T., Clarysse, B., Groen, A., 2012. The evolution of business incubators: comparing demand and supply of business incubation services across different incubator generations. Technovation 32, 110-121.

Brush, C.G., Greene, P.G., Hart, M.M., 2001. From initial idea to unique advantage: the entrepreneurial challenge of constructing a resource base. Acad. Manag. Exec. 15, 64-78.

Bruton, G.D., Ahlstrom, D., Li, H.L., 2010. Institutional theory and entrepreneurship: where are we now and where do we need to move in the future? Entrep. Theory Pract. 34, 421-440.

Busenitz, L.W., Barney, J.B., 1997. Differences between entrepreneurs and managers in large organizations: biases and heuristics in strategic decision-making. J. Bus. Ventur. 12, 9-30.

Carayannis, E.G., Popescu, D., Sipp, C., Stewart, M., 2006. Technological learning for entrepreneurial development (TL4ED) in the knowledge economy (KE): case studies and lessons learned. Technovation 26, 419-443.

Carpenter, R., Petersen, B., 2002. Capital market imperfections, high-tech investment, and new equity financing. Econ. J. 112, 54-72.

Chrisman, J.J., McMullan, E., Hall, J., 2005. The influence of guided preparation on the long-term performance of new ventures. J. Bus. Ventur. 20, 769-791.

Clarysse, B., Wright, M., Lockett, A., Van de Velde, E., Vohora, A., 2005. Spinning out new ventures: a typology of incubation strategies from European research institutions. J. Bus. Ventur. 20, 183-216.

Climate-KIC, 2014. Climate-KIC [WWW Document]. URL 〈www.climate-kic.org) (accessed 06.20.14).

Cooper, C.E., Hamel, S.A., Connaughton, S.L., 2010. Motivations and obstacles to networking in a university business incubator. J. Technol. Transf. 37, 433-453.

Corbin, J., Strauss, A., 1990. Grounded theory research: procedures, canons, and evaluative criteria. Qual. Sociol. 13, 4-21.

Costa-David, J., Malan, J., Lalkaka, R., 2002. Improving Business Incubator Performance through Benchmarking and Evaluation: Lessons Learned from Europe In: Proceedings of the 16th International Conference on Business Incubation, National Business Incubation Association. April 28 - May 1. Toronto, Canada.

Cyert, R., March, J., 1963. A Behavioral Theory of the Firm, Englewood Cliffs, NJ. Prentice-Hall, Englewood Cliffs, NJ, New Jersey.

Honig Davidsson, P., 2003. The role of social and human capital among nascent entrepreneurs. J. Bus. Ventur. 18, 301-331.

Dee, N.J., Livesey, F., Gill, D., Minshall, T., 2011. Incubation for Growth. A Review of the impact of business incubation on new ventures with high growth potential. London.

Eisenhardt, K., 1989. Building theories from case study research. Acad. Manag. Rev. 14, 532-550.

Etzkowitz, H., 2002. Incubation of incubators: innovation as a triple helix of university-industry-government networks. Sci. Public Policy 29, 115-128.

Ferguson, R., Olofsson, C., 2004. Science parks and the development of NTBFslocation, survival and growth. J. Technol. Transf. 29, 5-17.

Garbuio, M., King, A.W., Lovallo, D., 2011. Looking inside: psychological influences on structuring a Firm's Portfolio of resources. J. Manag. 37, 1444-1463.

Gassmann, O., Becker, B., 2006. Towards a resource-based view of corporate incubators. Int. J. Innov. Manag. 10, 19-45.

Gioia, D.A., Corley, K.G., Hamilton, A.L., 2012. Seeking qualitative rigor in inductive research: notes on the Gioia Methodology. Organ. Res. Methods 16, 15-31.

Glaser, B.G., Strauss, A.L., 1967. The Discovery of Grounded Theory: Strategies for Qualitative Research. Aldine, Chicago,IL.

Gompers, P., Lerner, J., 2001. The venture capital revolution. J. Econ. Perspect. 15, $145-168$.

Grant, R.M., 1991. The resource-based theory of competitive advantage: implications for strategy formulation. Calif. Manag. Rev. 33, 114-135.

Grant, R.M.R., 1996. Toward a knowledge-based theory of the firm. Strateg. Manag. J. 17, 109-122.

Hackett, S.M., Dilts, D.M., 2004. A systematic review of business incubation research. J. Technol. Transf. 29, 55-82.

Hansen, M.T., Chesbrough, H.W., Nohria, N., Sull, D.N., 2000. Networked incubators. Hothouses of the new economy. Harv. Bus. Rev. 78, 74-84.
Hite, J., Hesterly, W., 2001. The evolution of firm networks: from emergence to early growth of the firm. Strateg. Manag. J. 22, 275-286.

Hughes, M., Ireland, R.D., Morgan, R.E., 2007. Stimulating dynamic value: social capital and business incubation as a pathway to competitive success. Long. Range Plan. 40, 154-177.

InBIA, 2016. International Business Incubation Association - Business Incubation FAQs [WWW Document]. URL $\langle$ Www.inbia.org $\rangle$ (accessed 02.01.16).

Ireland, R., 2003. A model of strategic entrepreneurship: the construct and its dimensions. J. Manag. 29, 963-989.

Lalkaka, R., 2001. Best practices in business incubation: Lessons (yet to be) learned in: International Conference on Business Centers, Actors of Economic and Social Development, Brussels, Belgium.

Lincoln, Y.S., Guba, E., 1986. Naturalistic Enquiry. Sage, Beverly Hills, CA.

McAdam, M., McAdam, R., 2008. High tech start-ups in University Science Park incubators: the relationship between the start-up's lifecycle progression and use of the incubator's resources. Technovation 28, 277-290.

Mian, S., 1997. Assessing and managing the university technology business incubator: an integrative framework. J. Bus. Ventur. 12, 251-285.

Mian, S., Lamine, W., Fayolle, A., 2016. Technology business incubation: an overview of the state of knowledge. Technovation 50-51, 1-12.

Oakey, R., 2003. Technical entreprenenurship in high technology small firms: some observations on the implications for management. Technovation 23, 679-688.

Oakey, R., 2012. High-Technology Entrepreneurship. Routledge, London and New York.

Oliver, C., 1997. Sustainable competitive advantage: combining institutional and resource-based views. Strateg. Manag. J. 18, 697-713.

Patton, D., 2014. Realising potential: the impact of business incubation on the absorptive capacity of new technology-based firms. Int. Small Bus. J. 32, 897-917.

Patton, D., Marlow, S., 2011. University technology business incubators: helping new entrepreneurial firms to learn to grow. Environ. Plan. C: Gov. Policy 29, 911-926.

Patton, D., Warren, L., Bream, D., 2009. Elements that underpin high-tech business incubation processes. J. Technol. Transf. 34, 621-636.

Pauwels, C., Clarysse, B., Wright, M., Hove, J. Van, 2016. Understanding a new generation incubation model: the accelerator. Technovation 50-51, 13-24.

Phan, P.H., Siegel, D.S., Wright, M., 2005. Science parks and incubators: observations, synthesis and future research. J. Bus. Ventur. 20, 165-182.

Quintane, E., Casselman, R., Reiche, B., Nylund, P., 2011. Innovation as a knowledgebased outcome. J. Knowl. Manag. 15, 928-947.

Rao, R.S., Chandy, R.K., Prabhu, J.C., 2008. The fruits of legitimacy: why some new ventures gain more from innovation than others. J. Mark. 72, 58-75.

Ratinho, T., Henriques, E., 2010. The role of science parks and business incubators in converging countries: evidence from Portugal. Technovation 30, 278-290.

Rice, M.P., 2002. Co-production of business assistance in business incubators: an exploratory study. J. Bus. Ventur. 17, 163-187.

Rotger, G.P., Gørtz, M., Storey, D.J., 2012. Assessing the effectiveness of guided preparation for new venture creation and performance: theory and practice. J. Bus. Ventur. 27, 506-521.

Rubin, T.H., Aas, T.H., Stead, A., 2015. Knowledge flow in technological business incubators: evidence from Australia and Israel. Technovation 41-42, 11-25.

Schwartz, M., 2009. Beyond incubation: an analysis of firm survival and exit dynamics in the post-graduation period. J. Technol. Transf. 34, 403-421.

Schwartz, M., 2013. A control group study of incubators' impact to promote firm survival. J. Technol. Transf. 38, 302-331.

Schwartz, M., Hornych, C., 2008. Specialization as strategy for business incubators: an assessment of the Central German Multimedia Center. Technovation 28, 436-449.

Schwartz, M., Hornych, C., 2010. Cooperation patterns of incubator firms and the impact of incubator specialization: empirical evidence from Germany. Technovation 30, 485-495.

Scillitoe, J.L., Chakrabarti, A.K., 2010. The role of incubator interactions in assisting new ventures. Technovation 30, 155-167.

Shane, S., Cable, D., 2002. Network ties, reputation, and the financing of new ventures. Manag. Sci. 48, 364-381.

Simon, M., Houghton, S.M., Aquino, K., 2000. Cognitive biases, risk perception, and venture formation: how individuals decide to start companies. J. Bus. Ventur. $15,113-134$.

Singh, J.V., Tucker, D.J., House, R.J., 1986. Organizational legitimacy and the liability of newness. Adm. Sci. Q. 31, 171-193.

Sirmon, D.G., Hitt, M.A., Ireland, R.D., 2007. Managing firm resources in dynamic environments to create value: looking inside the black box. Acad. Manag. Rev. 32, 273-292.

Soetanto, D., Jack, S.L., 2016. The impact of university-based incubation support on the innovation strategy of academic spin-offs. Technovation 50-51, 25-40.

Soetanto, D.P., Jack, S.L., 2013. Business incubators and the networks of technologybased firms. J. Technol. Transf. 38, 432-453.

Stam, E., 2015. Entrepreneurial ecosystems and regional policy: a sympathetic critique. Eur. Plan. Stud. 23, 1759-1769.

Stam, W., Arzlanian, S., Elfring, T., 2014. Social capital of entrepreneurs and small firm performance: a meta-analysis of contextual and methodological moderators. J. Bus. Ventur. 29, 152-173.

Stinchcombe, A., 1965. Social structure and organizations. In: March, J. (Ed.), Handbook of Organizations. Rand McNally, Chicago,IL, pp. 260-290.

Stokan, E., Thompson, L., Mahu, R.J., 2015. Testing the differential effect of business incubators on firm growth. Econ. Dev. Q. 29, 317-327.

Sullivan, D.M., Marvel, M.R., 2011. Knowledge acquisition, network reliance, and 
early-stage technology venture outcomes. J. Manag. Stud. 48, 1169-1193.

Tamásy, C., 2007. Rethinking technology-oriented business incubators: developing a robust policy instrument for entrepreneurship, innovation, and regional development. Growth Change 38, 460-473.

Tavoletti, E., 2013. Business incubators: effective infrastructures or waste of public money? Looking for a theoretical framework, guidelines and criteria. J. Knowl. Econ. 4, 423-443.

Theodorakopoulos, N., Kakabadse, N., McGowan, C., 2014. What matters in business incubation? A literature review and a suggestion for situated theorising. J. Small Bus. Enterp. Dev. 21, 602-622.
Totterman, H., Sten, J., 2005. Start-ups: business incubation and social sapital. Int. Small Bus. J. 23, 487-511.

Vohora, A., Wright, M., Lockett, A., 2004. Critical junctures in the development of university high-tech spinout companies. Res. Policy 33, 147-175.

Wernerfelt, B., 1984. A resource-based view of the firm. Strateg. Manag. J. 5, $171-180$.

Westhead, P., Storey, D., 1997. Financial constraints on the growth of high technology small firms in the United Kingdom. Applied Financial Economics. 7, pp. 197-201. 